\title{
Beyond harm's reach? Submersion of river turtle nesting areas and implications for restoration actions after Amazon hydropower development
}

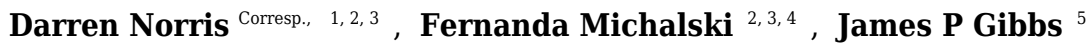 \\ ${ }^{1}$ School of Environmental Sciences, Federal University of Amapá, Macapá, Amapá, Brazil \\ 3 Postgraduate Programme in Tropical Biodiversity, Federal University of Amapá, Macapá, Amapá, Brazil \\ 4 Instituto Pró-Carnívoros, Atibaia, São Paulo, Brazil \\ 5 Department of Forest and Environmental Biology, State University of New York (SUNY), Syracuse, New York, United States of America \\ Corresponding Author: Darren Norris \\ Email address: darren.norris@unifap.br
}

The global expansion of energy demands combined with abundant rainfall, large water volumes and high flow in tropical rivers have led to an unprecedented expansion of dam constructions in the Amazon. This expansion generates an urgent need for refined approaches to river management; specifically a move away from decision-making governed by overly generalized guidelines. For the first time we quantify direct impacts of hydropower reservoir establishment on an Amazon fresh water turtle. We conducted surveys along $150 \mathrm{~km}$ of rivers upstream of a new dam construction during the low water months that correspond to the nesting season of Podocnemis unifilis in the study area. Comparison of nest-areas before $(2011,2015)$ and after $(2016)$ reservoir filling show that reservoir impacts extend $13 \%$ beyond legally defined limits. The submerged nesting areas accounted for a total of 3.8 ha of nesting habitat that was inundated as a direct result of the reservoir filling in 2016. Our findings highlight limitations in the development and implementation of existing Brazilian environmental impact assessment process. We also propose potential ways to mitigate the negative impacts of dams on freshwater turtles and the Amazonian freshwater ecosystems they inhabit. 
1 Beyond harm's reach? Submersion of river turtle nesting areas and implications for restoration actions

2 after Amazon hydropower development

3 Authors: Darren Norris ${ }^{1,2,3^{*}}$, Fernanda Michalski ${ }^{2,3,4}$, James P. Gibbs ${ }^{5}$

$4 \quad{ }^{1}$ School of Environmental Sciences, Federal University of Amapá, Macapá, Amapá, Brazil

$5{ }^{2}$ Ecology and Conservation of Amazonian Vertebrates Research Group, Federal University of Amapá,

6 Macapá, Brazil

$7 \quad{ }^{3}$ Postgraduate Programme in Tropical Biodiversity, Federal University of Amapá, Macapá, Brazil

$8{ }^{4}$ Instituto Pró-Carnívoros, Atibaia, São Paulo, Brazil

$9{ }^{5}$ Department of Forest and Environmental Biology, State University of New York (SUNY), Syracuse, New

10 York, United States of America

$11 *$ Corresponding author

12 E-mail: darren.norris@unifap.br (DN) 


\section{Abstract}

14 The global expansion of energy demands combined with abundant rainfall, large water volumes and high

15 flow in tropical rivers have led to an unprecedented expansion of dam constructions in the Amazon. This

16 expansion generates an urgent need for refined approaches to river management; specifically a move

17 away from decision-making governed by overly generalized guidelines. For the first time we quantify

18 direct impacts of hydropower reservoir establishment on an Amazon fresh water turtle. We conducted

19 surveys along $150 \mathrm{~km}$ of rivers upstream of a new dam construction during the low water months that correspond to the nesting season of Podocnemis unifilis in the study area. Comparison of nest-areas before $(2011,2015)$ and after (2016) reservoir filling show that reservoir impacts extend $13 \%$ beyond legally defined limits. The submerged nesting areas accounted for a total of 3.8 ha of nesting habitat that was inundated as a direct result of the reservoir filling in 2016. Our findings highlight limitations in the development and implementation of existing Brazilian environmental impact assessment process. We also propose potential ways to mitigate the negative impacts of dams on freshwater turtles and the Amazonian freshwater ecosystems they inhabit. 


\section{Introduction}

28 Freshwater turtles are under threat from the alteration of rivers, habitat loss, climatic changes and anthropogenic changes to the landscape. In aquatic systems, changes in upstream land use and the placement of dams have had significant impacts on ecosystems and turtle populations worldwide (Castello et al. 2013; Lees et al. 2016; Rhodin et al. 2011; Rödder \& Ihlow 2013). Despite this, the literature on environmental impact assessments of dams on freshwater turtles is limited, as most dams are constructed before any baseline ecological data were collected (Keck et al. 2017; Poff \& Zimmerman 2010; Sousa Júnior et al. 2016).

There is an urgent need for refined approaches to river management, and a move away from decision-making governed by overly generalized rules of thumb (Keck et al. 2017; Kuehne et al. 2017; Latrubesse et al. 2017). Hydroelectric expansion generates myriad social (Richter \& Thomas 2007; Zedler \& Callaway 1999), economic and environmental changes (Freeman et al. 2007; Kingsford 2000; Molle 2009). Generally dams accumulate toxins and release greenhouse gases, which combined with regional deforestation, can generate drastic changes in local and regional climates (Guimberteau et al. 2017; Stickler et al. 2013). These changes have disproportionately large effects on the communities and biodiversity that are nearest to the installation site. This is particularly true in the Amazon basin, where freshwater ecosystems are vital components and hydrological connectivity with both aquatic and terrestrial ecosystems makes them susceptible to a wider range of anthropogenic impacts at local and regional scale (Castello et al. 2013; Latrubesse et al. 2017). Thus, the debate as to whether hydropower is renewable continues (Fearnside 2016; Ferreira et al. 2014; Kahn et al. 2014; Winemiller et al. 2016). at the global-scale dams and water resources challenges remain all too common in economically developed (e.g. Australia) and developing (e.g. Brazil with its large economy but low per capita GDP) nations (Sousa Júnior et al. 2016; Tundisi et al. 2014). The 6.15 million $\mathrm{km}^{2}$ Amazon River basin is by far

51 the largest river basin in the world, with the Amazon River discharge contributing more than $15 \%$ of the 
52 total discharge of all rivers (FAO 2016) playing a key role in maintaining global climate and hydrological

53 cycles. Across the Amazon, transnational river systems and a lack of coordinated management of aquatic

54 systems may result in losses to unspecified levels of biodiversity (Castello et al. 2013; Fearnside 2016;

55 Ferreira et al. 2014; Latrubesse et al. 2017; Sousa Júnior et al. 2016; Winemiller et al. 2016). Ensuring the

56 social and environmental sustainability of the myriad developments across Amazon waterways is

57 therefore critical for future regional and global well-being (Kahn et al. 2014; Latrubesse et al. 2017; Tilt et

58 al. 2009).

59 Environmental impact assessment (EIA) systems in Brazil are at a crossroads (Ferreira et al. 2014).

Environmental impact assessments are the mechanism used to ensure environmental sustainability of major development projects. The purpose of impact assessment is to evaluate whether a stressor has and/or will change the environment, which components are adversely affected, and to estimate the magnitude of the effects. Impact assessments are best based on before-after control-impact (BACI) design (Smith 2006). An appropriately applied BACl design is considered optimal to help isolate the effect of the development from natural variability. Yet, due to myriad financial, logistical and political reasons BACl-designed studies are relatively rare and empirical impact assessments are most commonly based on so-called space-for-time substitutions. There is increasing evidence that such space-for-time assessments can systematically underestimate impacts of stressors/changes (França et al. 2016; Gonzalez et al. 2016). downstream impacts can reach, as this knowledge is required to directly inform specific strategies and solutions to mitigate the myriad adverse effects on biodiversity and freshwater ecosystems. The spatial extent of upstream impacts depends on the local system channel geometry, channel slope, and height of the dam. New dams present a unique challenge to freshwater turtles in the region as reservoir formation

74 and flow changes can drastically alter feeding and breeding habits, due to irreversible changes in

75 phenological rhythms of the flooded forest, and submerging of nesting beaches used by Amazonian

76 freshwater turtles (Castello et al. 2013; Lees et al. 2016). 
Our objective was to identify the distance at which the reservoir from a medium-sized dam

impacted populations of the yellow spotted river turtle (Podocnemis unifilis). We quantified and mapped

nesting areas pre- and post-reservoir formation to identify the spatial limit of reservoir flooding on this

species. To maximize strength of inference our study employed a before-after comparison, which is

lacking in most studies of hydropower development (Poff \& Zimmerman 2010). Based on project

outcomes, we discuss potential ways to mitigate the negative effects of hydropower development on

83 Amazonian freshwater turtles.

\section{Ethical statement}

\section{Material and methods}

\section{Study area} Permit number 1.013.843).
Ethical approval was not required for our noninvasive study, as we did not collect any biological sample nor interfere with the behavior of the study species. Permission to collect observational data from river turtle nest-areas was provided by research permit number IBAMA/SISBIO 49632-1 and 49632-2 to DN and FM, issued by the Instituto Chico Mendes de Conservação da Biodiversidade (ICMBio). Interviews with local residents were approved by IBAMA/SISBIO (permits 45034-1, 45034-2, 45034-3) and the Ethics Committee in Research from the Federal University of Amapá (UNIFAP) (CAAE 42064815.5.0000.0003,

The study was conducted in the Araguari River basin, upriver of the newly installed Cachoeira Caldeirão Dam, in the state of Amapá, Brazil (N 0.77327, W 51.58064; Fig 1). The regional climate is classified by Köppen-Geiger as Am (Equatorial monsoon) (Kottek et al. 2006), with an annual rainfall greater than 2000 mm (ANA 2016). The driest months are September to November (total monthly rainfall $<150 \mathrm{~mm}$ ) and the wettest months (total monthly rainfall > $300 \mathrm{~mm}$ ) from February to April (S1 Fig in Paredes et al. 
99 (2017)). The Araguari River rises in the Guianan Shield at the base of the Tumucumaque uplands and until

100 recently discharged directly into the Atlantic Ocean (i.e. was not part of the Amazon River basin).

101 However, in 2015 the river course changed due to as yet undefined anthropogenic effects and the

102 Araguari River now discharges directly into both the Atlantic Ocean (120 km east from the Cachoeira

103 Caldeirão Dam) and the Amazon River (100 km south from the Cachoeira Caldeirão Dam).

104 The Cachoeira Caldeirão is a large run-of-river dam (219 MW, dam height 20.6 m), with three

105 turbines that became fully operational in January 2017 (EDP energy 2017). The Cachoeira Caldeirão is the

106 third and most recent addition to a series of dams along a $20 \mathrm{~km}$ stretch of the Araguari River. The

107 reservoir was filled in January 2016, and the testing of the first installed turbine started on 24 February

1082016 (ANEEL 2016). The approved Cachoeira Caldeirão reservoir extended to an altitude of 58.3 masl,

109 with a volume of $230.56 \mathrm{hm}^{3}$, covering an area of $47.99 \mathrm{~km}^{2}$ (including $24 \mathrm{~km}^{2}$ of flooding beyond the

110 original river channels) and an average depth of $4.8 \mathrm{~m}$ (EDP energy 2017).

111 The Cachoeira Caldeirão dam and hydropower plant was built, installed and is currently operated

112 by the Empresa de Energia Cachoeira Caldeirão S.A, which is a joint venture between China Three Gorges

113 Brasil (member of the China Three Gorges Corporation) and EDP - Energias do Brasil S.A (subsidiary of

114 EDP - Energias de Portugal) (Bloomberg L.P. 2017). Environmental Impact Assessments (EIAs) are required

115 before any of the installation work can be started (Fearnside 2016). These EIAs are paid for by the

116 operating company (Empresa de Energia Cachoeira Caldeirão S.A), who contract companies (in this case

117 Eletronorte, Odebrecht and Neoenergia) to evaluate the overall viability of the project. These companies

118 subsequently subcontract the EIA to specialized consultancy firms.

\section{Study species}

The semi-aquatic yellow spotted river turtle ( $P$. unifilis) is widely distributed across lentic and lotic 
122 Guyana, French Guiana and Suriname) (Vogt 2008). Although P. unifilis is widespread, anthropogenic

123 impacts such as hunting, nest harvesting, and deforestation means that the species is classified as

124 Vulnerable (A1acd) by the IUCN (Tortoise \& Freshwater Turtle Specialist Group 1996; Vogt 2008). As

125 found in many turtle species, nest site selection is an important component of $P$. unfilis demographics

126 (Escalona et al. 2009; Iverson 1991). Females are thought to lay eggs once a year, with the timing of

127 nesting synchronized with seasonal periods of low water levels (Ojasti 1996; Vogt 2008). Females can lay

128 nests in a wide variety of substrates (Escalona et al. 2009; Foote 1978; Pignati et al. 2013), with nesting

129 recorded in pasture (Ramon dos Santos 2013) and even on top of caiman nests (Maffeil \& Da Silveirall

130 2013). However, such examples are atypical. More typically P. unifilis nesting shows a nonrandom

131 pattern; with nesting areas sharing similar environmental characteristics such as beaches and river banks

132 with dry and relatively exposed sandy-silty substrates (Escalona et al. 2009; Pignati et al. 2013).

\section{Nest-area surveys}

134 Surveys were conducted between September and December in three nesting seasons, two pre- (2011,

1352015 ) and one post- (2016) reservoir formation. These months correspond to low water and include the

136 complete nesting and first half of the hatching season in the study area (D. Norris pers. obs.). Nesting

137 area data from 2011 were obtained from a previous study along $66 \mathrm{~km}$ of river (Arraes 2012). In 2015 and

138 2016, we then repeated and extended the methodologies applied in 2011, along $150 \mathrm{~km}$ of river

139 upstream of the Cachoeira Caldeirão dam (Fig 1).

140 Surveys started $12 \mathrm{~km}$ upstream of the dam. This start point was established in 2011, and in

$1412015 / 2016$ it was not possible to safely conduct monthly surveys closer to the dam due to the operations

142 that coincided with the survey period (e.g. involving boats, dredgers, and construction). Surveys were

143 used to identify and map nesting areas. Originally in 2011, two separate $33 \mathrm{~km}$ river sections were

144 surveyed for nesting areas, the first starting $12 \mathrm{~km}$ upstream from the dam. The 2011 survey 
145 methodology was extended in 2015 and 2016, when we surveyed a continuous $150 \mathrm{~km}$ stretch of river

146 and also considered both potential and actual nesting areas. Potential nesting areas are all locations that

147 had suitable habitat conditions for nesting but where no nests were found and actual nesting areas those 148 locations where females actually nested.

149 Methods used to identify turtle nest-areas were standardized among years. To minimize possible 150 detectability bias related to the searches of turtle nesting areas and nests we maintained at least one 151 observer in the team constant while conducting searches in all years (2011, 2015, and 2016). Monthly 152 boat surveys were used to identify nesting areas. While navigating along the rivers in a motorized boat at 153 a constant speed (ca. $10 \mathrm{~km} / \mathrm{h}$ ) we performed an extensive search for nesting areas that involved 154 identifying potentially suitable areas through visually searching river banks, circling islands, stopping to 155 search among boulders and rapids. These searches were conducted together with local residents with over 30 years of knowledge of nesting areas. We identified potential areas (Figure S1 A-B) where

157 environmental conditions matched those described in the literature (Escalona et al. 2009; Pignati et al. 158 2013) and/or those found at the nesting areas from 2011. These potential areas were identified based on 159 the presence of at least $1 \mathrm{~m}^{2}$ of exposed sand and/or fine gravel substrate, raised sufficiently high above 160 the river level to not be waterlogged at a depth of $15 \mathrm{~cm}$, which is representative of the depth females dig 161 when nesting (depth to first egg is typically $7-10 \mathrm{~cm}$, D. Norris pers. obs., (Pignati et al. 2013)). Based on 162 the diversity of nesting areas along $150 \mathrm{~km}$ of river in the study area (Figure S1), we did not include slope 163 as a selection criteria. Sites that remained waterlogged (on or close to the water level) or predominantly 164 covered with an inappropriate substrate type (e.g. clay, large pebbles) were characterized as not suitable 165 for nesting (Figure S1 D-E).

166 Potential areas were repeatedly surveyed to locate nests (each area being surveyed three times 167 per season with an interval of 20 - 30 days between visits), once a nest was confirmed the area was considered as an actual nesting area. All nesting areas were characterized in terms of size and shape by mapping in the field using a handheld GPS and confirmed against high-resolution satellite images 
170 [RapidEye, $5 \mathrm{~m}$ resolution, downloaded from http://geocatalogo.mma.gov.br; Tile IDs: 2239415 (date

171 10/09/2015), 2239412 (date 22/09/2015) and 2239413 (date 20/10/2015)]. We mapped only the surface

172 area considered to be suitable for turtle nesting, i.e. excluding areas covered by rock/prominent

173 boulders/roots/clay substrates.

174 To locate river turtle nests we conducted monthly surveys of all nesting areas. Nests were located

175 by following turtle tracks on the sandy/gravel substrates and systematic substrate searches. Searches

176 were conducted by a team of three observers at a standardized speed (mean 0.8 , range $0.2-1.3 \mathrm{~km}$ per

177 hour) and the time spent searching sites ranged from 10 to 97 minutes depending on the size of the site.

178 To identify actual nest-areas we considered the presence of all nests including those predated by humans

179 or wildlife. Depredated nests were identified by the presence of broken eggshells outside the nest,

180 disturbed/uncovered nests and the presence of excavation marks.

181 Female turtles are thought to repeatedly use the same nesting areas, but considering the

182 possibility that there could be differences in the locations of nest-areas used between years and that

183 despite our intensive effort we may have failed to detect some nests, we also conducted interviews with

184 local residents to identify actual river turtle nest-areas during the last 5 years (Norris \& Michalski 2013).

185 Thus, nest areas that were reported by interviewees and those where nests were identified during field

186 surveys were both included as actual areas in our study. Sites with river turtle tracks but no confirmed

187 nesting were included in the potential nesting area count.

\section{Data analysis}

189 All statistical analyses were undertaken within the R language and environment for statistical computing

190 (R Core Team 2017). Variation in the number of nesting areas per km was examined using a generalized

191 linear model (GLM) with Tweedie error distribution family (Dunn 2017). Tweedie is a probability

192 distribution family that includes the purely continuous normal and gamma distributions, the purely

193 discrete Poisson distribution, and the class of compound Poisson-gamma distributions (Jorgensen 1997; 
194 Tweedie 1984). A maximum likelihood method (function "tweedie.profile") was used to profile the

195 Tweedie variance function index parameter $p$. The profiling generated an estimate of 1.155, which

196 corresponds to a compound Poisson-gamma distribution (Jorgensen 1997). This compound Poisson

197 distribution is particularly useful for modelling responses with a continuous distribution on positive

198 values but with some observations being exactly zero (Jorgensen 1997). The error distribution family was

199 modelled with the tweedie package default log-link power function.

200 To represent the $\mathrm{BACl}$ design, the response of actual nesting beaches per $\mathrm{km}$ was modelled against

201 two fixed factors, i) before-after and ii) control-impact. The impacted area corresponds to $33 \mathrm{~km}$ of the

202 Araguari River, within the area of direct impact (as defined by the EIA (Ecotumucumaque 2013; EDP

203 energy 2017)), 12-45 km upstream of the dam (Fig 1). For control areas, we used a $33 \mathrm{~km}$ stretch of the

204 Falsino river 61-94 km upstream of the dam (Fig 1), which corresponds to a region with little

205 anthropogenic disturbance, with less than five households (Norris \& Michalski 2013) and fisherman are

206 not allowed to enter. For the GLM analysis each area (control, impact) was divided into five subsections

207 with an equal length of $6.6 \mathrm{~km}$ (Table S1). This distance was chosen to provide a representative number

208 of spatially independent replicates for model estimation. Greater numbers of shorter sections resulted in

209 higher proportions of river sections with zero nesting areas, which consequently reduced the

210 performance of GLM estimation and fit. We also included the interaction between factors, where a

211 significant interaction represents differences between the impacted area compared with the control after

212 the reservoir filling (Underwood 1993).

213 To examine the spatial extent of submersion we considered potential and actual nest-areas up to

214 the farthest submerged nest-area. To determine the distance of each nest-area from the dam, we

215 obtained the center of each nest-area polygon and then calculated the distance along the river between

216 each center point and the dam using functions available in the $\mathrm{R}$ ( $\mathrm{R}$ Core Team 2017) package riverdist

217 (Tyers 2017). As continuous surveys of nesting areas were not conducted in 2011, analysis of the spatial

218 extent of nest-area submersion was conducted by comparing data collected in 2015 (pre-reservoir 
219 formation) and 2016 (post-reservoir formation). A nesting area could be either potential or actual during

220 the nesting period. That is, if a potential area was identified and in a subsequent visit a nest was found

221 then the area was counted only as actual during the nesting season.

\section{Results}

223 Prior to reservoir filling we encountered on average 0.5 river-turtle nesting areas per $\mathrm{km}$ along $66 \mathrm{~km}$ of

224 rivers (Fig 2). Although there tended to be more nesting areas in control sections (0.7 per km compared

225 with 0.4 per $\mathrm{km}$ in the impacted sections), there was no significant difference between the mean

226 numbers of nest-areas encountered in control and impacted river sections prior to reservoir filling [Table

227 1, Table S1, Fig 2 (95\% confidence intervals overlap sample means)]. Following reservoir filling there was

228 a drastic reduction in the number of nesting areas encountered along the $33 \mathrm{~km}$ within the impacted

229 area (0.065 areas per km, Fig. 2$)$. This decline was a clearly different pattern from the relatively stable

230 number of nesting areas encountered in the control sections (Fig 2, Table 1 GLM interaction term P=

231 0.041).

232

Reservoir filling reduced the overall (potential and actual) nesting area to $17 \%$ of the pre-filling

baseline along $57.4 \mathrm{~km}$ of river upstream of the dam (Table 2). A total of 3.8 ha of nest-areas (both

potential and actual) were submerged as a direct result of the reservoir filling in 2016 (Fig 3, Table S2). Of

this total, 1.6 ha of actual nest-areas were submerged and $13 \%$ ( 0.2 ha) of these actual nest-area losses

occurred beyond the legally defined limit of direct impact (Fig 3). The farthest submerged nest-area was a

$520 \mathrm{~m}^{2}$ actual nest-area, located $57.4 \mathrm{~km}$ from the dam and $20.2 \mathrm{~km}$ upstream of the limit of direct

impact defined by the environmental impact assessment (Fig 3). Beyond this point none of the areas actual nest-areas in 2016.

241 In addition to complete submersion, there was a drastic reduction in the size of the remaining

242 actual nesting areas (Table 2). Overall fewer nests were encountered in 2016, but the density of nests at 
243 the remaining sites increased nearly three-fold. This increased density was correlated with both a

244 reduction in nest-area area and an increased number of nests per area, with the mean number of nests

245 encountered increasing by 50\% from the 2015 baseline (from 1.4 to 2.1 nests per area in 2016). Overall

246 nest mortality was high, with only one nest successfully hatching in 2015 and none in 2016 . In both years

247 the majority of nests were removed by humans (Table 2). Areas with multiple nests were most strongly

248 affected by humans (mean removal 98\%), whereas there was no human removal of nests from areas with

249 only one nest.

250 Discussion

251 For the first time we present a representative and robust before-after control-impact comparison that

252 establishes a minimum value for the spatial extent of the direct impacts of a hydropower development

253 on an Amazon river turtle. Our findings support a growing body of research that shows that without

254 direct conservation intervention river turtles are unlikely to survive the severity and speed of

255 environmental changes caused by hydroelectric development (Ihlow et al. 2012; Rhodin et al. 2011;

256 Rödder \& Ihlow 2013). We first explore the extent of nest-area lost due to submersion, and then turn to

257 explore how negative impacts caused by a dam reservoir can extend beyond environmental impact

258 assessment limits. Finally, we discuss ways to mitigate the negative effects of dam construction in

259 freshwater river turtles.

\section{Extent of nest-area loss/submersion}

261 Our results showed that a total of 3.8 ha of nest-areas were submerged as a direct result of the new

262 hydropower reservoir filling in 2016, which accounted for the loss of 85 (25.4\%) actual/potential nest-

263 areas in the study area. We cannot attribute nest-area differences across years to detectability bias of

264 observers as we maintained at least one observer from the local community constant in all three survey 
265 years (pre- and post-dam). Thus, we can assume that differences reported here between year

266 comparisons are not related to any systematic bias in methods and/or observers.

$267 \quad$ Nest-areas are representative of river turtle populations and have been studied for several

268 purposes but mainly for population estimation (Pignati et al. 2013) and evaluation of sustainable harvest

269 (Caputo et al. 2005). Yet, traditional population demographic parameters are time consuming to obtain at

270 the scale of areas affected by hydropower developments and will not necessarily provide information

271 that is urgently needed to inform effective conservation actions and solutions. We, therefore, present

272 representative data on nest-area submersion that reflects negative effects caused by the new

273 hydropower dam construction on freshwater turtles.

274 We found that the dam of a hydropower development permanently submerged actual and

275 potential nest-areas where $P$. unifilis used to make nests. Similar results have been found across the

276 Amazon, with studies showing that hydropower disruption of flows and natural seasonal flood-pulses

277 severely compromises biodiversity along Amazon rivers (Castello et al. 2013; Fearnside 2009; Latrubesse

278 et al. 2017; Lees et al. 2016; Sousa Júnior et al. 2016; Winemiller et al. 2016). Thus, with a quarter of the

279 actual/potential nest-areas used by turtles in our study area directly affected by water submersion, we

280 showed that females lost areas used for nesting and will need to find new nesting sites. As female turtles

281 are thought to exhibit a strong degree of nest-area fidelity (Valenzuela \& Janzen 2001) we anticipate

282 increased adult mortality as a direct result of loss of nest areas. Females will have to search for new

283 areas, which increases exposure to predators and energy expenditure at a time when females need to

284 invest in development of eggs. Additionally, dispersal movements used to fulfill reproductive life

285 requirements due to the new reservoir filling may generate conflicts with other resident turtles (Alho

286 2011), rendering energy demand and turtle density alterations with potential conflict for food resource

287 and non-flooded potential nest-areas.

$288 \quad$ Environmental changes caused by hydropower development will not only reduce nesting success

289 but will also cause outright loss of population segments. For example, in North America, approximately 6- 
290

291

293

294

295

$98 \mathrm{~m}$ of land is required to encompass each consecutive $10 \%$ segment of a freshwater turtle nesting population up to $90 \%$ coverage, with ca. $424 \mathrm{~m}$ being required to encompass the remaining $10 \%$ (Steen et al. 2012). While some freshwater turtles require modest terrestrial areas ( $<200 \mathrm{~m}$ zones) for $95 \%$ nest coverage, others require larger zones (Steen et al. 2012). Additionally, a 30 year study of Blanding's Turtles indicated that $39 \%$ of females and $50 \%$ of males captured, maintained the same residence wetland for over 20 years in southeastern Michigan (Congdon et al. 2011).

We expect that loss of potential nesting areas will concentrate and intensify human nest removal on remaining areas. We found that the density of nests at the remaining un-flooded areas increased by nearly three-fold with an increased number of nests per area. Changes in turtle nest densities have been shown to increase predation, with clumped nests depredated at a greater rate than scattered nests (Marchand et al. 2002). Considering that $P$. unifilis is widely consumed and traded in the Amazon region (Peres 2000; Pezzuti et al. 2010; Smith 1979), and eggs and adults are also being consumed in our study region (Norris \& Michalski 2013), we anticipate that human nest removal is likely to increase. Within our study area humans are by far the dominant predator of turtle nests. Currently, the local riverine people remove $76-77 \%$ of turtle nests. Therefore, the reductions in areas where nests can be laid coupled with increased nest density in a smaller number of areas will likely concentrate and intensify human nest removal on the few remaining areas. The consumption of river turtle eggs by local people may also increase due to the complex social impacts associated with dam and reservoir creation, such as the resettlement of displaced populations, loss of fish and other resources by riverine communities (Fearnside 2001; Tilt et al. 2009), coupled with the destruction of the previously occupied physical space (Finley-Brook \& Thomas 2010).

\section{Implications for restoration of freshwater ecosystems}

312 Our findings support the view that when placed within scenarios of rapid and poorly planned

313 anthropogenic development, the recovery of biodiversity (from ecosystems to populations) is unlikely 
314 without direct interventions (Latrubesse et al. 2017; Lees et al. 2016; Tundisi et al. 2014). BACl is not

315 required for Brazilian environmental impact assessments. This means that environmental impact

316 assessments generally lack scientific rigor, depending largely on simulations to predict impacts and space-

317 for-time comparisons for evaluation and monitoring. Remote sensing is a step forward and has been used

318 to generate detailed understanding of broad regional scale impacts and consequences of hydropower

319 developments in the Amazon basin (Fearnside 2009; Fearnside \& Pueyo 2012; Latrubesse et al. 2017;

320 Stickler et al. 2013). Yet, lack of BACl studies at the local scale limits our ability to generate biodiversity

321 compensation or restoration actions. Recent reviews demonstrate a lack of robust data (Alho 2011; Lees

322 et al. 2016). Such data is necessary to inform effective impact assessments, and its absence limits the

323 efficiency of proposed management procedures for conservation, restoration and sustainable use.

$324 \quad$ Our results show that restoration actions for our study area must replace at least 1.5 ha of suitable

325 substrate for actual river turtle nest areas. If we consider the total area (actual + potential), then at least

3263.8 ha of suitable nesting habitat must be restored. The enhancement/formation of reservoir islands for

327 conservation is also necessary and has already been proposed to mitigate negative effects of dams

328 (McCartney 2009). Such actions enable the integration of social (as points for leisure and environmental

329 education) and biodiversity conservation objectives. Yet, such restoration actions are unlikely to succeed

330 in isolation. Considering the levels of human nest removal, additional measures will be necessary for the

331 long term conservation of river turtles in the area. Environmental education campaigns aiming to reduce

332 turtle egg consumption, a cultural habit established in the study area (Norris \& Michalski 2013), will be a

333 critical component for the timely mitigation of the negative impacts of dam constructions.

334 Humans are compensated (albeit often unfairly/incompletely) when their land has been

335 completely or partially submerged by a hydropower reservoir (Fearnside 2001; Fearnside 2016; Tilt et al.

336 2009). Yet restoration actions have not been anticipated and/or implemented for this widespread semi-

337 aquatic species of turtle, which holds cultural, economic and ecological significance. Brazil has the legal

338 structure to implement statutes and legally oblige developments to implement 
339 biodiversity/environmental compensation actions. A recent example of Brazilian legislation generating

340 positive biodiversity outcomes is the case where anticipated hydropower development impacts on

341 indigenous lands halted (at least temporarily) one hydropower development in Mato Grosso State

342 (Bergen 2016). But the impacts of other neighboring dams in this same area show the harsh reality.

343 Whilst other nations strengthen environmental laws, Brazilian legislation allows sacred areas to be

344 dynamited and provides awards to those responsible (Branford \& Torres 2017). Unfortunately, recent

345 proposals, under consideration in the Brazilian congress ("Câmara dos Deputados") are likely to further

346 weaken existing environmental legislation (Azevedo-Santos et al. 2017; Fearnside 2016). These cases

347 highlight the continued need for robust science, including data collected from BACl designs to inform

348 ongoing political debates within Brazil.

\section{Conclusions}

350 We conclude that freshwater turtles considered in this study were highly vulnerable to nest-area losses

351 due to submersion of actual and potential nest-areas in 2016 as a direct result of river level rises caused

352 by the Cachoeira Caldeirão Dam. The synergistic effects of the construction of the new reservoir coupled

353 with the alterations in nest density in the remaining nest-areas will likely affect negatively freshwater

354 turtles. Additionally, the social impacts on human riverine populations and the loss of resources such as

355 fish are likely to increase the consumption of freshwater turtle eggs. These factors are likely to act

356 synergistically with nest area losses to drastically reduce freshwater turtle populations. Despite the at

357 least temporary persistence of $P$. unifilis nests in the study area, there is little evidence that this species

358 will be able to cope with the severe reduction in nest-areas associated with human removal of nests in

359 the near future. Populations of freshwater turtles are likely to succumb if mitigation is not undertaken

360 both during and after reservoir formation. However, additional research on post-dam construction effects

361 such as population level information on how freshwater turtles deal with such drastic environmental

362 changes are necessary to support the development of effective conservation solutions. As a minimum 
363 conservation strategy, mitigation of pervasive negative effects of the new reservoir should be

364 implemented to ameliorate devastating effects on turtles and other semi-aquatic species.

\section{Acknowledgments}

366 The Instituto Chico Mendes de Conservação da Biodiversidade (ICMBio) and the Federal University of

367 Amapá (UNIFAP) provided logistical support. We are grateful to Alvino Pantoja Leal, Cremilson, Cleonaldo

368 and Cledinaldo Alves Marques for their invaluable assistance during fieldwork. We thank the editor

369 Jonathan D Tonkin and Erin Abernethy and Daniel Escoriza for their helpful revision of earlier versions of 370 the text.

\section{References}

372 Alho CJR. 2011. Environmental effects of hydropower reservoirs on wild mammals and freshwater turtles

373 in Amazonia: a review. Oecologia Australis 15:593-604. 10.4257/oeco.2011.1503.11

374 ANA. 2016. Agência Nacional de Águas (National Water Agency): Sistema de Monitoramento Hidrológico

375 (Hydrological Monitoring System). Available at http://www.hidroweb.ana.gov.br (accessed 20

$376 \quad$ July 2016).

377 ANEEL. 2016. Relatório de Acompanhamento da Implantação de Emprendimentos de Geração. Available at http://www.aneel.gov.br/documents/655816/14483518/Relat

$379 \quad$ \%C3\%B3rio+de+Acompanhamento+da+Implanta

380

\%C3\%A7\%C3\%A3o+de+Empreendimentos+de+Gera\%C3\%A7\%C3\%A3o+-+Abril+2016/67e6dffb-

381 f140-40ed-afb2-a11449f03dc4?version=1.0 (accessed 12 April 2017). 
382

383

384

385

386

387

388

389

390

391

392

Arraes DRS. 2012. Nidificação, neonatos e a influência da pressão antrópica em tracajá Podocnemis unifilis TROSCHEL, 1848 (Podocnemididae) na bacia do Rio Araguari, Amazônia Oriental, Brasil MSc Dissertation. Universidade Federal do Amapá. Available at http://www2.unifap.br/ppgbio/files/2010/05/D\%C3\%89BORA-ARRAES-DISSERTA \%C3\%87\%C3\%830-NIDIFICA\%C3\%87\%C3\%830-NEONATOS-E-A-INFLUE.pdf (accessed 12 March 2016).

Azevedo-Santos VM, Fearnside PM, Oliveira CS, Padial AA, Pelicice FM, Lima DP, Simberloff D, Lovejoy TE, Magalhães ALB, Orsi ML, Agostinho AA, Esteves FA, Pompeu PS, Laurance WF, Petrere M, Mormul RP, and Vitule JRS. 2017. Removing the abyss between conservation science and policy decisions in Brazil. Biodiversity and Conservation 26:1745-1752. 10.1007/s10531-017-1316-x

Bergen M. 2016. Halt in construction of Brazilian dam sign of progress on indigenous rights. Available at http://blog.conservation.org/2016/04/halt-in-construction-of-brazilian-dam-sign-of-progress-onindigenous-rights/ (accessed 30 May 2017).

Bloomberg L.P. 2017. Company Overview of Empresa de Energia Cachoeira Caldeirão S.A. Available at https://www.bloomberg.com/research/stocks/private/snapshot.asp?privcapld=252828616 (accessed 21 November 2017).

Branford S, and Torres M. 2017. Is Brazil green washing hydropower? The case of the Teles Pires dam. Available at https://news.mongabay.com/2017/01/is-brazil-green-washing-hydropower-thecase-of-the-teles-pires-dam/ (accessed 30 May 2017).

Caputo FP, Canestrelli D, and Boitani L. 2005. Conserving the terecay (Podocnemis uinifilis, Testudines : Pelomedusidae) through a community-based sustainable harvest of its eggs. Biological Conservation 126:84-92. 10.1016/j.biocon.2005.05.004

Castello L, McGrath DG, Hess LL, Coe MT, Lefebvre PA, Petry P, Macedo MN, Renó VF, and Arantes CC. 2013. The vulnerability of Amazon freshwater ecosystems. Conservation Letters 6:217-229. 10.1111/conl.12008 
407 Congdon JD, Kinney OM, and Nagle RD. 2011. Spatial ecology and core-area protection of Blanding's 408 Turtle (Emydoidea blandingii). Canadian Journal of Zoology-Revue Canadienne De Zoologie $409 \quad$ 89:1098-1106. 10.1139/z11-091

410 Dunn PK. 2017. Tweedie: Evaluation of Tweedie exponential family models. R package version 2.3. $411 \quad$ Available at https://cran.r-project.org/web/packages/tweedie.

412 Ecotumucumaque. 2013. Plano Básico Ambiental do Aproveitamento Hidrelétrico Cachoeira Caldeirão. 413 Macapá, Amapá. Available at http://www.cachoeiraenergia.com.br/.

414 EDP energy. 2017. Cachoeira Caldeirão Technical data (Cachoeira Caldeirão Dados Técnicos). Available at http://www.edp.com.br/geracao-renovaveis/geracao/amapa-para/uhe-cachoeira-caldeirao/ausina/Paginas/dados-tecnicos.aspx (accessed 12 April 2017).

417 Escalona T, Valenzuela N, and Adams DC. 2009. Nesting ecology in the freshwater turtle Podocnemis unifilis: spatiotemporal patterns and inferred explanations. Functional Ecology 23:826-835.

FAO. 2016. AQUASTAT website. Food and Agriculture Organization of the United Nations (FAO). Available at http://www.fao.org/nr/water/aquastat/basins/amazon/index.stm (accessed 30 May 2017).

Fearnside PM. 2001. Environmental impacts of Brazil's Tucuruí Dam: Unlearned lessons for hydroelectric development in Amazonia. Environmental Management 27:377-396.

Fearnside PM. 2016. Tropical dams: To build or not to build? Science 351:456-457. 
431 Ferreira J, Aragão LEOC, Barlow J, Barreto P, Berenguer E, Bustamante M, Gardner TA, Lees AC, Lima A,

432

433

434

435

436

437

438

439

440

441
Louzada J, Pardini R, Parry L, Peres CA, Pompeu PS, Tabarelli M, and Zuanon J. 2014. Brazil's environmental leadership at risk. Science 346:706-707. 10.1126/science.1260194

Finley-Brook M, and Thomas C. 2010. Treatment of displaced indigenous populations in two large hydro projects in Panama. Water Alternatives 3:269.

Foote RW. 1978. Nesting of Podocnemis unifilis (Testudines: Pelomedusidae) in the Colombian Amazon. Herpetologica 34:333-339.

França F, Louzada J, Korasaki V, Griffiths H, Silveira JM, and Barlow J. 2016. Do space-for-time assessments underestimate the impacts of logging on tropical biodiversity? An Amazonian case study using dung beetles. Journal of Applied Ecology 53:1098-1105. 10.1111/1365-2664.12657

Freeman MC, Pringle CM, and Jackson CR. 2007. Hydrologic connectivity and the contribution of stream headwaters to ecological integrity at regional scales. Journal of the American Water Resources Association 43:5-14. 10.1111/j.1752-1688.2007.00002.x

Gonzalez A, Cardinale BJ, Allington GRH, Byrnes J, Arthur Endsley K, Brown DG, Hooper DU, Isbell F, O'Connor MI, and Loreau M. 2016. Estimating local biodiversity change: a critique of papers claiming no net loss of local diversity. Ecology 97:1949-1960. 10.1890/15-1759.1

Guimberteau M, Ciais P, Ducharne A, Boisier JP, Aguiar APD, Biemans H, De Deurwaerder H, Galbraith D, Kruijt B, and Langerwisch F. 2017. Impacts of future deforestation and climate change on the hydrology of the Amazon Basin: a multi-model analysis with a new set of land-cover change scenarios. Hydrology and Earth System Sciences 21:1455. 10.5194/hess-21-1455-2017

Ihlow F, Dambach J, Engler JO, Flecks M, Hartmann T, Nekum S, Rajaei H, and Rödder D. 2012. On the brink of extinction? How climate change may affect global chelonian species richness and distribution. Global Change Biology 18:1520-1530. 10.1111/j.1365-2486.2011.02623.x

Iverson JB. 1991. Patterns of survivorship in turtles (order Testudines). Canadian Journal of Zoology 69:385-391. 10.1139/z91-060 
456 Jorgensen B. 1997. The theory of dispersion models: CRC Press.

457 Kahn RJ, Freitas EC, and Petrere M. 2014. False Shades of Green: The Case of Brazilian Amazonian

$458 \quad$ Hydropower. Energies 7. 10.3390/en7096063

459 Keck F, Vasselon V, Tapolczai K, Rimet F, and Bouchez A. 2017. Freshwater biomonitoring in the 460 Information Age. Frontiers in Ecology and the Environment 15:266-274. 10.1002/fee.1490

461 Kingsford RT. 2000. Ecological impacts of dams, water diversions and river management on floodplain 462 wetlands in Australia. Austral Ecology 25:109-127. 10.1111/j.1442-9993.2000.tb00012.x

Kottek M, Grieser J, Beck C, Rudolf B, and Rubel F. 2006. World map of the Koppen-Geiger climate classification updated. Meteorologische Zeitschrift 15:259-263. 10.1127/0941-2948/2006/0130

Kuehne LM, Olden JD, Strecker AL, Lawler JJ, and Theobald DM. 2017. Past, present, and future of ecological integrity assessment for fresh waters. Frontiers in Ecology and the Environment 15:197-205. 10.1002/fee.1483

Latrubesse EM, Arima EY, Dunne T, Park E, Baker VR, d'Horta FM, Wight C, Wittmann F, Zuanon J, Baker PA, Ribas CC, Norgaard RB, Filizola N, Ansar A, Flyvbjerg B, and Stevaux JC. 2017. Damming the rivers of the Amazon basin. Nature 546:363. 10.1038/nature22333

Lees AC, Peres CA, Fearnside PM, Schneider M, and Zuanon JAS. 2016. Hydropower and the future of Amazonian biodiversity. Biodiversity and Conservation 25:451-466. 10.1007/s10531-016-1072-3

Maffeil F, and Da Silveirall R. 2013. First record of multiple nests of yellow-spotted river turtle (Podocnemis unifilis) in a nest of black caiman (Melanosuchus niger) in Amazonia. Boletim do Museu Paraense Emilio Goeldi - Ciências Naturais 8:461-465.

Marchand MN, Litvaitis JA, Maier TJ, and DeGraaf RM. 2002. Use of Artificial Nests to Investigate Predation on Freshwater Turtle Nests. Wildlife Society Bulletin (1973-2006) 30:1092-1098.

McCartney M. 2009. Living with dams: managing the environmental impacts. Water Policy 11:121-139. 10.2166/wp.2009.108 
480 Molle F. 2009. River-basin planning and management: The social life of a concept. Geoforum 40:484-494.

$481 \quad$ 10.1016/j.geoforum.2009.03.004

482 Norris D, and Michalski F. 2013. Socio-economic and spatial determinants of anthropogenic predation on 483 Yellow-spotted River Tuttle, Podocnemis unifilis (Testudines: Pelomedusidae), nests in the 484 Brazilian Amazon: Implications for sustainable conservation and management. Zoologia 30:482490. $10.1590 / s 1984-46702013000500003$

Ojasti J. 1996. Wildlife utilization in Latin America: current situation and prospects for sustainable ONE 12:e0174049.

Peres CA. 2000. Effects of subsistence hunting on vertebrate community structure in Amazonian forests.

Pezzuti JCB, Lima JP, da Silva DF, and Begossi A. 2010. Uses and Taboos of Turtles and Tortoises Along Rio Negro, Amazon Basin. Journal of Ethnobiology 30:153-168. 10.2993/0278-0771-30.1.153

Poff NL, and Zimmerman JKH. 2010. Ecological responses to altered flow regimes: a literature review to inform the science and management of environmental flows. Freshwater Biology 55:194-205. 10.1111/j.1365-2427.2009.02272.x

R Core Team. 2017. R: A Language and Environment for Statistical Computing. 3.4.2. Available at https://www.R-project.org/. 
504 Ramon dos Santos D. 2013. Primeiro registro de nidificacao de Podocnemis unifilis (Testudines,

505 Podocnemididae) em uma area de pasto no municipiio de Montes Claros de Goias, Brasil. Revista

506 Sapiência: sociedade, saberes e práticas educacionais 2:29-37.

507 Rhodin A, Walde A, Horne B, Van Dijk P, Blanck T, and Hudson R. 2011. Turtles in trouble: the world's 25+

508 most endangered tortoises and freshwater turtles-2011: Turtle Conservation Coalition.

$509 \quad$ Available at http://www.iucn-tftsg.org/top-25-2011/.

510 Richter BD, and Thomas GA. 2007. Restoring environmental flows by modifying dam operations. Ecology

$511 \quad$ and Society 12:12.

512 Rödder D, and Ihlow F. 2013. Chelonians in a changing climate: can nest site selection prevent sex ratio

$513 \quad$ skews? Animal Conservation 16:491-492. 10.1111/acv.12079

514 Smith EP. 2006. BACI Design. Encyclopedia of Environmetrics: John Wiley \& Sons, Ltd.

515 Smith NJH. 1979. Aquatic turtles of Amazonia: an endangered resource. Biological Conservation:165-176.

$516 \quad 10.1016 / 0006-3207(79) 90019-3$

517 Sousa Júnior W, Baldwin C, Camkin J, Fidelman P, Silva O, Neto S, and Smith T. 2016. Water: Drought,

$518 \quad$ Crisis and Governance in Australia and Brazil. Water 8:493. 10.3390/w8110493

519 Steen DA, Gibbs JP, Buhlmann KA, Carr JL, Compton BW, Congdon JD, Doody JS, Godwin JC, Holcomb KL, 520 Jackson DR, Janzen FJ, Johnson G, Jones MT, Lamer JT, Langen TA, Plummer MV, Rowe JW,

521 Saumure RA, Tucker JK, and Wilson DS. 2012. Terrestrial habitat requirements of nesting

522 freshwater turtles. Biological Conservation 150:121-128. 10.1016/j.biocon.2012.03.012

523 Stickler CM, Coe MT, Costa MH, Nepstad DC, McGrath DG, Dias LCP, Rodrigues HO, and Soares-Filho BS.

524 2013. Dependence of hydropower energy generation on forests in the Amazon Basin at local and

525 regional scales. Proceedings of the National Academy of Sciences 110:9601-9606.

$526 \quad 10.1073 /$ pnas.1215331110 
527 Tilt B, Braun Y, and He D. 2009. Social impacts of large dam projects: A comparison of international case 528 studies and implications for best practice. Journal of environmental management 90:S249-S257. $529 \quad$ 10.1016/j.jenvman.2008.07.030

530 Tortoise \& Freshwater Turtle Specialist Group. 1996. Podocnemis unifilis (errata version published in 2016). IUCN 2017 IUCN Red List of Threatened Species Version 20172. Gland: IUCN Switzerland.

Tundisi JG, Goldemberg J, Matsumura-Tundisi T, and Saraiva ACF. 2014. How many more dams in the Amazon? Energy Policy 74:703-708. 10.1016/j.enpol.2014.07.013

Tweedie M. 1984. An index which distinguishes between some important exponential families. Statistics: Applications and new directions: Proc Indian Statistical Institute Golden Jubilee International

Tyers M. 2017. riverdist: River Network Distance Computation and Applications. R package version 0.14.0. Available at https://CRAN.R-project.org/package=riverdist.

Underwood AJ. 1993. The mechanics of spatially replicated sampling programmes to detect

Valenzuela N, and Janzen FJ. 2001. Nest-site philopatry and the evolution of temperature-dependent sex

Vogt R. 2008. Tartarugas da Amazonia. Manaus: INPA.

545 Winemiller KO, McIntyre PB, Castello L, Fluet-Chouinard E, Giarrizzo T, Nam S, Baird IG, Darwall W, Lujan 546 NK, Harrison I, Stiassny MLJ, Silvano RAM, Fitzgerald DB, Pelicice FM, Agostinho AA, Gomes LC, Albert JS, Baran E, Petrere M, Zarfl C, Mulligan M, Sullivan JP, Arantes CC, Sousa LM, Koning AA, Hoeinghaus DJ, Sabaj M, Lundberg JG, Armbruster J, Thieme ML, Petry P, Zuanon J, Vilara GT, 
552 Zedler JB, and Callaway JC. 1999. Tracking wetland restoration: Do mitigation sites follow desired

553 trajectories? Restoration Ecology 7:69-73. 10.1046/j.1526-100X.1999.07108.x 


\section{Table $\mathbf{1}$ (on next page)}

Comparison of nesting areas in control and impacted river sections before and after reservoir filling.

Results from GLM used to explain the variation in the number of nesting areas per $\mathrm{km}$ of river, recorded before $(2011,2015)$ and after (2016) hydropower reservoir filling. Nesting area surveys were conducted along $33 \mathrm{~km}$ in both control (61 - $94 \mathrm{~km}$ upstream) and directly impacted (12 - $45 \mathrm{~km}$ upstream) river sections in all years 


\begin{tabular}{lccccc}
\hline & & Actual nesting areas per kilometer \\
& Source of variation & Estimate & SE & T value & $P^{\mathrm{a}}$ \\
\hline (Intercept) & 1.08 & 0.05 & 21.90 & $<0.001$
\end{tabular}

Before-after (compared with 2011)

\begin{tabular}{rrrrr}
2015 & -0.04 & 0.06 & -0.66 & 0.519 \\
2016 & 0.01 & 0.07 & 0.18 & 0.857 \\
Control-impact (impact vs control) & 0.05 & 0.08 & 0.68 & 0.506 \\
Interaction (Before-after:Control-impact) & & & & \\
2015:Impact & 0.02 & 0.10 & 0.25 & 0.804 \\
2016:Impact & 0.37 & 0.14 & 1.89 & 0.041 \\
\hline
\end{tabular}

Observations

30

Model deviance explained (\%)

37.0

Model $P^{\mathrm{b}}$

0.0398

1 aFactor $P$ values obtained from comparison against the $\mathrm{t}$ statistic probability distribution.

2 bModel $P$ value obtained from comparison against single factor (control-impact) null model. 


\section{Table 2 (on next page)}

Nesting areas encountered along the Araguari river basin.

Comparison of nesting areas recorded before (2015) and after (2016) hydropower reservoir filling. Potential nest areas had suitable habitat for nesting but no nests were detected and actual areas are where females nested in 2015 and/or in the previous five years (2010 2014). 
1

\begin{tabular}{lccccc}
\hline Year & $\begin{array}{c}\text { No. nesting } \\
\text { areas } \\
\text { (potential, } \\
\text { actual) }\end{array}$ & $\begin{array}{c}\text { Total nesting area } \\
\text { (ha) (potential, } \\
\text { actual) }\end{array}$ & $\begin{array}{c}\text { Mean nesting area } \\
\text { (ha) (potential, } \\
\text { actual) }\end{array}$ & $\begin{array}{c}\text { Nest } \\
\text { density }(\mathrm{N})\end{array}$ & $\begin{array}{l}\text { Human } \\
\text { removal (N) }\end{array}$ \\
\hline 2015 & $114(80,34)$ & $5.2(2.61,2.60)$ & $0.03(0.03,0.08)$ & $18.9(49)$ & $76 \%(37)$ \\
2016 & $29(15,14)$ & $0.9(0.38,0.56)$ & $0.04(0.03,0.04)$ & $53.6(30)$ & $77 \%(23)$ \\
\hline aNests per ha of actual nesting areas.
\end{tabular}




\section{Figure 1}

Study area.

(A) State of Amapá in Brazil. (B) Location within Amapá. (C) Showing location of submerged (triangles) and unsubmerged (circles) Podocnemis unifilis nest-areas. Yellow shading delimits the area directly impacted by the Cachoeira Caldeirão Dam (blue square) as defined by the environmental impact assessment. Location of the multiyear (2011, 2015 and 2016) controlimpact survey areas are indicated along the rivers. Impact surveys were conducted along the directly impacted river section and control surveys along a river section between 22.9 and $55.9 \mathrm{~km}$ upstream of the directly impacted zone.
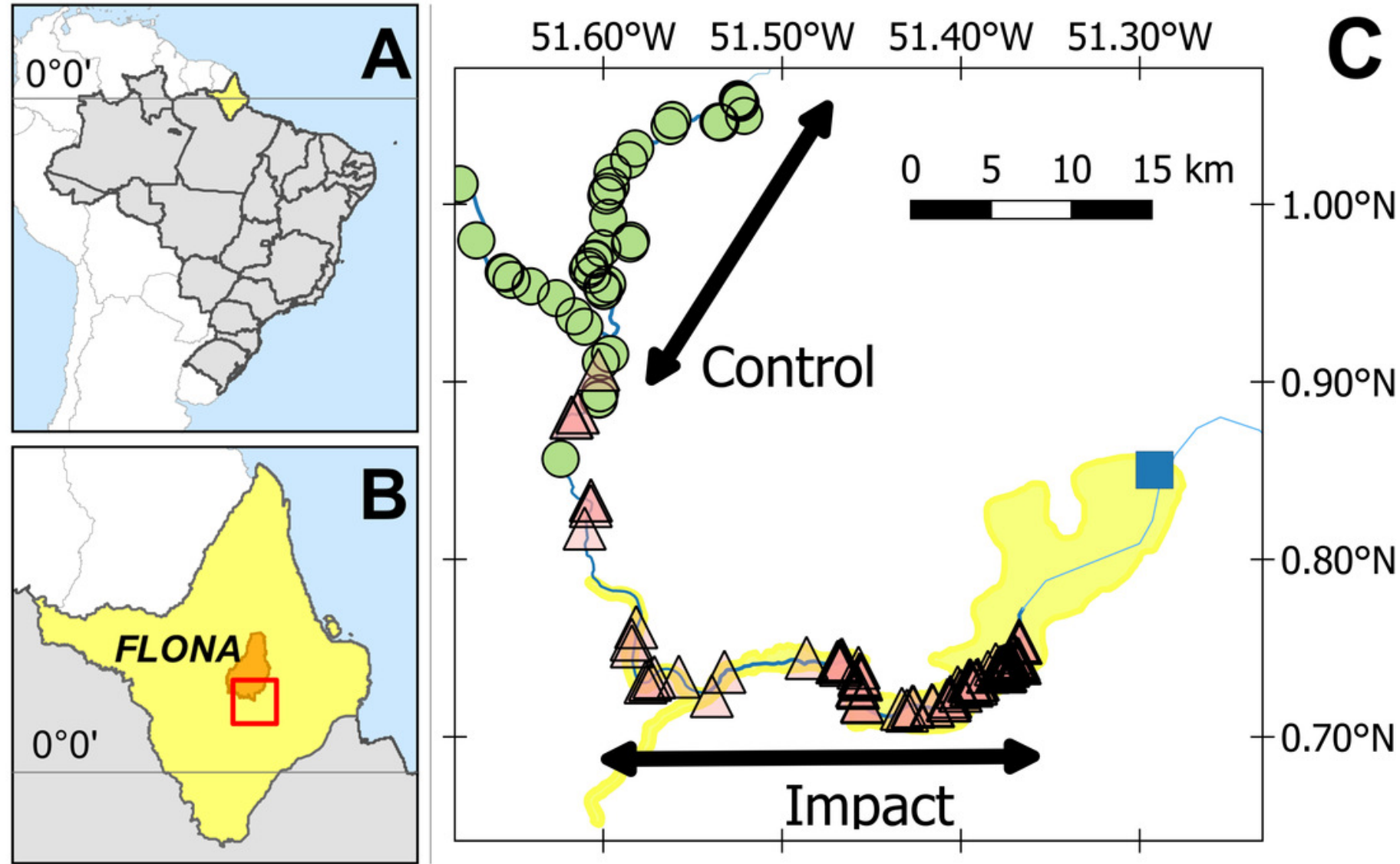


\section{Figure 2 (on next page)}

Nesting areas before and after reservoir filling

Number of yellow spotted river turtle nesting areas encountered during two nesting seasons before $(2011,2015)$ and one nesting season following (2016) reservoir filling of the Cachoeira Caldeirão Dam. Nesting area surveys were conducted along $33 \mathrm{~km}$ in both control (61 - 94 km upstream) and directly impacted (12 - $45 \mathrm{~km}$ upstream) river sections. Points show means and solid vertical lines are 95\% confidence limits estimated via nonparametric bootstrap. Surveys were conducted simultaneously but points have been dodged along the $x$ axis for clarity. Dashed vertical line represents when the reservoir was filled. 
Figure 3

Submersion of river turtle nest-areas.

(A) cumulative area (ha) and (B) cumulative count of nest-areas submerged by reservoir formation at the Cachoeira Caldeirão Dam, Amapá, Brazil. Potential nest-areas had suitable habitat for nesting but no nests were detected and actual are those areas where females nested in 2015 and/or in the previous five years (2010 - 2014). Dashed vertical line represents the limit of direct impact defined by the environmental impact assessment. Lines and shaded areas are mean values and 95\% confidence intervals from Generalized Additive Models (formula $=y \sim s(x, k=4$, bs $=" c s ")$ ) that are added as a visual aid to illustrate trends in the cumulative values.

(A)

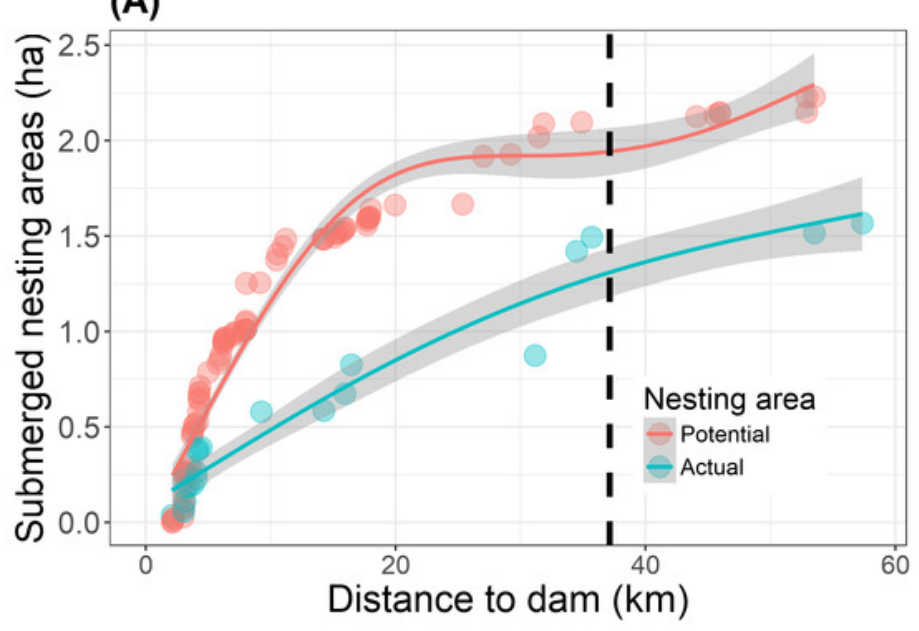

(B)

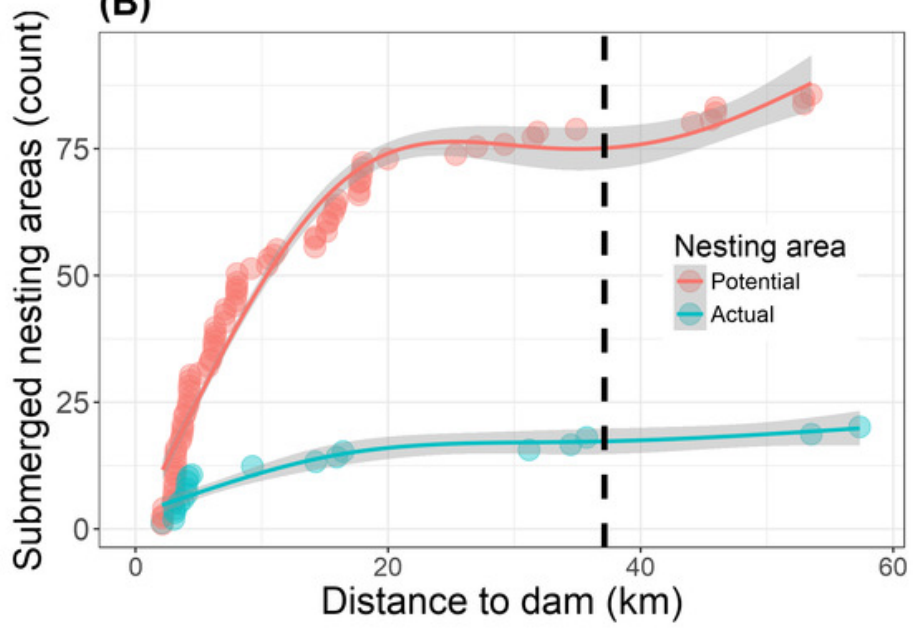

